

\title{
LI.-A supplement to the synopsis of the fishes of Madeira in the second volume of the transactions of the Zoological Society
}

\section{Rev. R.T. Lowe}

To cite this article: Rev. R.T. Lowe (1840) LI._A supplement to the synopsis of the fishes of Madeira in the second volume of the transactions of the Zoological Society , Annals and Magazine of Natural History, 4:26, 405-424, DOI: 10.1080/00222934009512515

To link to this article: http://dx.doi.org/10.1080/00222934009512515

曲 Published online: 15 Mar 2010.

Submit your article to this journal $₫$ 
in the latter, and on which the peculiar value of this species seems to depend, is a large spindle-shaped organ about half the length of the fish, thick in the middle and tapering toward the extremities, where it ends in front by two, and behind by a single tendinous cord; similar small tendinous attachments, about twenty-two in number, connect it on either side to the upper and lateral parts of the abdominal cavity. This organ, which is called the sound, is to be removed, opened, and stript of a thin vascular membrane which covers it both within and without, washed perhaps with lime water and exposed to the sun, when it will soon become dry and hard; it may require some further preparation to deprive it of its fishy smell, after which it may be drawn into shreds for the purpose of rendering it the more easily soluble. The fish which I examined weighed about two pounds and yielded about sixty-five grains of Isinglass, not quite pure, but containing about 10 per cent. of albuminous matter, owing perhaps to the individual from which it was taken being young and out of season, and not above a tenth part of the ordinary size of the species. But the solution after having been strained appeared to be equal to that of the best Isinglass, which costs in Calcutta from twelve to sixteen rupees a pound. As the subject thus seemed to be of consequence, I gave a portion of the substance in question to Dr. O'Shaughnessy for its chemical examination.

Calcutta, 3rd May, 1839.

LI.-A Supplement to the Synopsis of the Fishes of Madeira* in the Second Volume of the Transactions of the Zoological Soriety. By the Rev. R. T. Lowe.

Fam. Percide.

Genus Callanthias.

Gen. char.-Head scaly, except the short muzzle before the eyes; teeth as in Anthias, B1.; preopercle perfectly entire; opercle with two flat adpressed spines; lateral line high up, near the back, and ending at the end of the dorsal fin, which is even or continuous; branchiostegous membrane with six rays.

Carlanthias paradigeus. A most elegant little fish ; in general habit and colouring resembling Anthias sacer, Bl., but without the produced third spine of the dorsal fin. Its analogies are singularly complicated, but its affinities are truly Percidous. By Bloch it might

* Read before the Zoological Society, May 28, 1839. 
have been arranged either in Bodianus or Cephalopholis, Bl., but it is really inadmissible into any well-defined or constituted modern genus. It is almost as rare as beautiful.

Fam. Berycidas.

Genus Beryx, Cuv.

Beryx decadactylus, Cuv. B. corpore ovali, lato, profundo, altitudine longitudinem capitis superante; dorso elevato, arcuato, gibbo ; ventre prominente: basi pinnce dorsalis elongato, pinnis pectoralibus haud breviore: oculis maximis : operculi angusti carina obscura: osse humerali angusto, margine posteriore recto, verticali.

D. $4+18-20$; Vs. $1+10$; \&c.

B. decadactylus, Cuv, and Val., Hist. III. 222.

B. splendens, nob. quoad icon. Tab. III. in Cam. Phil. Trans., Vol. VI. Part 1 ; haud textus.

When I published $B$. splendens as a new species in the Cambridge Transactions, I was unacquainted with the present fish, though it is scarcely perhaps less common than the former. I consequently did not discover till long after, that the figure intended for my $B$. splendens had been inadvertently taken by Miss Young from an individual of $B$. decadactylus, Cuv., of which it offers the more obvious peculiarities. The true B. splendens, therefore, yet remains unfigured, and till an opportunity presents of supplying this deficiency in the "Fishes of Madeira," I subjoin its true specific characters, contrasted with those of $B$. decadactylus.

B. SPLENDENS. B. corpore oblongo, altitudine longitudinem capitis haud aquante: dorso recto : basi pinne dorsalis brevi, pinnis pectoralibus breviore : oculis magnis ; operculi lati carina prominente: osse humerali dilatato, margine posteriore arcuato, obliquo.

D. $4+13-15$; V. $1+10-13(1+11$ fere $) ; \& c$.

B. splendens, nob. Proceed. Zool. Soc. 1833. 1. 142. Cam. Phil. Trans. VI. 1. 197; excl. icon.-Syn. Mad. Fishes in Trans. Zool. Soc. Vol. ii. p. 174.

Trachichthys pretiosus, nob.

Hoplostethus mediterraneus, Cuv. and Val. IV. 496. t. 97. bis. Rariss.

This fish is unquestionably congeneric, if it is not even still more closely allied with Trachichthys australis of Shaw. Hence the above adoption of the older generic appellation, affording opportunity for the substitution of a less restrictive specific title; better suited to a fish : proved by the occurrence of two individuals in these Atlantic seas not to be peculiarly Mediterranean.

To the Sub-Percidous family Berycide belongs also Polymixia; 
nob. Cam. Phil. Trans. IV. 1. 198. t. IV.-Syn. Mad. Fish. pp. 178, 179.

\section{Fam. Triglide.}

Trigla lineata, L. Cuv. and Val. Hist. IV. 34.; Yarrell, Brit. Fish. 1. 46. Rariss.

A single individual only has occurred.

Fam. Sparida.

Pagellus rostratus, nob.-Syn. Mad. Fish. 177.

Reference to the excellently characteristic figures of Rondelet and Salviani has satisfied me that this is merely Pagellus erythrinus, Cuv. and Val.

Fam. Chetodontida.

Pimelepterus Boscii, Lac._" Cheiroco" or " Xarroco."-Cuv. and Val. VII. 258. t. 187. Rariss.

\section{Fam. Scombrida.}

Thynnus Albacora.- "Atum Albacora."-T. corpore elongato, postice attenuato: pinna anali secundaque dorsali antice longe falcatoproductis: pectoralibus ad medium secunda dorsalis attingentibus : ore oculisque parvis.

Tunny, Penn. Brit. Zool. Ed. 1. iii. 266. No. 133. t. 52. excl. syn. An L'Auxide de Sloane, Scomber Sloanei, Cuv. and Val. Hist. VIII. 148 ; i. e. Albacore, Sloane, Hist. of Jam. 1. t. 1. f. p. 28 ? Sat. vulg.

The length of the narrow produced fore-part of the second dorsal fin varies from one-sixth to one-fourth part of the whole length of the fish; that of the pectoral fins is from one-fifth to one-fourth part of the same, and their tips reach to the middle of the second dorsal fin. Thus, in this latter point it is intermediate between the common Tunny ( $T$. vulgaris, L.) and the following new species ( $T$. obesus, nob.); approaching most the latter.

Pennant's figure is at least a tolerable representation of this very distinct species, agreeing with it in its main points of difference from the true $T$. vulgaris, L. It may be hoped that the attention of British Naturalists will be directed to this point. The proper season for the Albacora in Madeira is September and October.

Thynvus obesus.- "Atum Patudo."-T. corpore abbreviato : obeso: pinnis acutis; pectoralibus ad finem secunda dorsalis attingentibus: oculis magnis.

Vulgaris.

This fish is constantly distinguished by the fishermen from the common Tunny or "Atum Rabilha" (T. vulgaris, L.) by the larger 
eye, and shorter thickset figure. The pectoral fins vary from onefourth to nearly one-sixth part of the whole length, their points reaching to the end of the second dorsal fin. In $T$. vulgaris, $L$. the tips of the pectoral fins reach only to the end of the first, or to the beginning of the second dorsal fin.

T. obesus is in greatest abundance earlier in the summer than $T$. Albacera. In size it ranges next below $T$. vulgaris, $L$., not however attaining above half the extreme size of that species; nor much exceeding the full size of $T$. Albacora.

Thynnus Alalonga, Cuv, and Val._."Atum Avoador."-Cuv, and Val. Hist. VIII. 120. t. 215.

Orcynus Alalonga, Risso, iii. 419. Vulgaris.

No difficulty can occur in the recognition of this species, from the great length of the pectoral fins, which are one-third part of the whole length, and reach to the end of the anal fin, or to the first spurious finlet behind it. Its proper season is said to be January.

Thyrsites acanthoderma.-_"Escolar."

Aplurus simplex, Syn. Mad. Fish. 180.

This is the fish called in my Synopsis Aplurus simplex. It is a true Thyrsites, Cuv. in every respect, except the structure of the skin, a peculiarity which seems insufficient, in the absence of all other characters, to warrant its generic separation.*

Prometheus atlanticus, nob.-_ Coelho."

This also is again here mentioned only for the sake of remarking. that further observations have gone far to prove the Maderan fish to be specifically distinct from both Gempylus Prometheus and G. Solandri of MM. Cuvier and Valenciennes, whose synonyms should therefore be expunged.

Gen. Aphanopus, nob.

Gen. Char.-Form as in Lepidopus, elongate, much compressed, like a sword-blade, naked, but with a short keel on each side, towards the tail.

Muzzle and teeth as in Lepidopus (Gouan), but the palatines unarmed.

Dorsal fins two, nearly equal. Anal fin as in Lepidopus, but with a strong sharp spine instead of a scale before it, a little behind the vent. No trace or rudiment of ventral fins.

Aphanopus carbo.- “Espada preta." Rariss.

Of this most curious new genus a single individual only has yet

- By an error in the punctuation, some descriptive observations at the bottom of page 180 of my synopsis (Trans. Zool. Soc., vol. ii.), relating to this fish, have been converted into a specific character. 
occurred. The whole fish is of a dark coffee colour, approaching to black, and has in form so close a general resemblance to Lepidopus argyreus, $\mathrm{Cuv}$., that it might well be taken hastily for a mere variety of that fish.

Tetragonurus atlanticus, nob.

Differs from T. Cuvieri, Cuv. and Val., XI. 172. $t$. 318. chiefly in the longer head, much larger eye (nearly twice as large in proportion to the whole length), greater width between the eyes, teeth twice as numerous, in the upper jaw ; thicker body, longer pectoral fins, higher (twice as high) first dorsal fin, and inequality of its spines. Having, however, seen only a single individual, I forbear to characterize it more distinctly; especially since of $T$. Cuvieri so few examples have as yet occurred; and that even MM. Cuvier and Valenciennes appear to have taken their figure from one which was imperfect in the caudal fin at least. The first dorsal fin is described by MM. Cuvier and Valenciennes as having fifteen spines; but twenty-one are figured in the plate.

The following is the fin-formula of T. Cuvieri, according to Risso; and MM. Cuv, and Val. :

"1st. D. 18; 2nd. D. 1, 12 ; A. 1, 11; P. 16; V.1,5; C.36." -Risso Hist.

“ 1 st. D. $\left\{\begin{array}{c}15 \text { in text, } \\ 21 \text { in fig. }\end{array}\right\}$ 2nd. D. $1+13 ;$ A. $12 ; P$ ?; V ?; C ?; B. M. 5."-Cuv. and Val. Hist.

That of $T$. atlanticus, nob. is

$$
\text { 1st. D. } 15 \text {; 2nd. D. } 11 \text {; A. } 11 \text {.; P. } 16 ; \text { V. } 1+5 ; \text { C. } \frac{7+\text { VIII. }}{7+\text { VII. }}
$$

B. M. 5.

The true affinities of this fish are certainly rather to be sought among the Mackerels (e.g. Thyrsites) than the Mullets. Its relation to the Mugilida is, indeed, one merely of a faint analogy.

Xiphias gladius, L.—"Peixe Agulha."

The ordinary Sword-fish of Madeira is truly the common Xiphias gladius, L.

I have heard, however, of " another sort, with a bayonet or spitlike beak," called "Peto," which may perhaps have been a Histiophorus or Tetrapturus.

SERIola DUbia. Rariss.

A single individual only has occurred, which I am unable to identify with any of the species enumerated by MM. Cuv, and Val. The second dorsal fin is produced in front into a point; five-eighths the depth of the body beneath. The sides of the tail are sufficiently distinctly keeled; and there is no temporal band. In the first of Ann. Nat. Hist. Vol. 4. No. 26. Feb. $1840 . \quad 2$ G 
these characters it comes nearest $S$. Rivoliana or $S$. falcata Cuv, and Val.; differing; however, from both, principally in the points in which they are said to agree with $S$. Dumerilii, Cuv. and Val. With S. Lalandi, Cuv. and Val., it agrees in the two latter points above-mentioned; but differs in the produced second dorsal and anal fins; S. Lalandi appearing from MM. Cuvier and Valenciennes' description not to disagree in this respect with $S$. Dumerilii, Cuv. and Val. The individual described measured two feet and a half long.

Lampris lauta. For "Vertebris 69" and "Vert. 49," in the specific character and following formula of the Lampris lauta, p, 183. Of the Synopsis of Fish Mad. (vol. ii. Trans. Zool. Soc.), read, Vertebris 45 ; and in the seventh line of the next page, for " six vertebræ more," read "two vertebræ more."

\section{Fam. Conyphanida.}

Coryphena hippurus, Cuv. and Val.? “Dourado macho."-Syn. Fish Mad. 183.

This fish agrees with $C$. hippuroïdes, Raf., according to the brief account transcribed by MM. Cuv. and Val., in having a row of larger dusky spots along the ridge of the back on each side at the base of the dorsal fin, which is itself immaculate, whilst the anal fin is also somewhat high and pointed in front. In these three points it is at variance with MM. Cuvier and Valenciennes' elaborate description of their C. hippurus, L. 'The individual described, however, by these consummate Ichthyologists was a male; whilst the only three which $I$ have been able to examine closely, proved on dissection to be females, though commonly supposed by the Maderan fisherman to be the male of C.equisetis, L. Hence the Maderan fish, whether identical or not with the obscure and doubtful C. hippuroïdes, Raf., is for the present better referred to $C$. hippurus, $L$. Sufficient ground appears for the suspicion that the above differences may be only sexual. But were it otherwise, they would alone scarcely warrant its specific dis. crimination.

\section{Coryphena Nortonians.- "Delfim."}

'This is a deeper fish than the preceding, in proportion to its length; with the front much steeper and bluffer; indeed, nearly vertical; the Dorsal fin beginning also somewhat forwarder. In the fin-formulæ, and number of the vertebræ (31), the two agree; and I have seen too few individuals at present to decide whether they really are distinct, or only so in sex. But for its spotted body, I should be greatly tempted to refer it to the imperfectly known C. imperialis, Raf. (See Cuv. and Val., Hist. 9, 286.) In this uncertainty as to 
both rank and synonyms, less ultimate confusion will result from a distinct specific name, applied provisionally, than from a doubtful reference. It is therefore called after the Honourable C. E. C. Norton, to whose able pencil I was first indebted for a knowledge of the fish. Two other supposed individuals have since occurred, of which, however, one was unfortunately neglected, and the other had been two much injured by a blow, beating in the interparietal crest, to be fully satisfactory. This last individual, taken November 22nd 1838, was apparently a male; but I could not satisfy myself completely even on this point, and infer it only from my inability to discover any trace of the ovaria.

Coryphena. equisetis, L. 1, 447.-“ Dourada," “D. femea," or “D. amarella."-C. equisetis, Cuv, and Val., 9, 297, $t .267$.

This may at once be distinguished from the foregoing species by its unspotted body, marked only by a few scattered, clear, but extremely minute black specks, very different from the diffused, pale, dusky, larger, spots of the preceding. The pectoral fins are also very short, the dorsal fin with fewer rays $(53-55)$, the number of vertebræ greater (33), the form deeper and less elongated than even in the first species here recorded. It also is a smaller fish. Being our commonest species, I have seen numerous examples, but none exceeding two feet in length. The average length is very uniformly from twenty to twenty-two or twenty-three inches.

This fish, which is the commonest of the "Dourados" of Madeira, differs from C. equisetis, L., as described by MM. Cuv. and Val., under the name of C.equisetis, only in the head being rather longer than high, instead of higher than long, in the dorsal fin being lower in its highest part, and also lower before than at its hinder end; and lastly in the profile being oblique from the beginning, whilst in $C$. equisetis, Cuv. and Val., " il monte d'abord verticalement sur le tiers à peu près de son contour." The first three discrepancies might well be merely due to slightly different modes of measurement. The latter is less easily accountable; for in this Maderan fish at least, of which I am well acquainted with both sexes, I find nothing to confirm M. Dussumier's observation, that a greater height of the interparietal crest is characteristic of the male in Coryphona. See Cuv. and Val. 12, Pref. p. vii.

Pompilus Rondeletii, Will. 215, t. O. 1,f.6.

Centrolophus pompilus, Yarr. 1, 158.

$$
\text { pompilus, Cuv. and Val. 9, 334, t. } 269 .
$$

morio (Lacep.) Ib. 342 . Rariss.

Two examples have occurred during the writing of this paper; 
the first was uniformly blackish, without spots or marks, thus answering to Centrolophus Morio of Lacepede : the second individual was smaller, and was marked precisely as in MM. Cuvier and Valenciennes' figure (t. 269) of C.pompilus.

I have no hesitation in uniting both these fishes, with their respective synonyms, under the name long since applied by Willoughby to designate the species; although by him employed especially in reference to the second state or variety abovementioned, which also was the variety originally described by Rondeletius.

Pompilus Bennettii.

Leirus Bennetii, nob. in Cam. Trans. VI. 1, 199, t. V.-Syn. Mad. Fish, p. 179.

Centrolophus ovalis, Cuv. and Val. IX. 346. crassus. Ib. 348.

The genus Leirus proves identical with Centrolophus, Lac., which in its turn, if not intolerable in itself (see Cuv. and Val. IX. 33 J.), must yield precedence to the prior claims of Pompilus, Rond. The species described by the Ichthyologist of Montpellier, (Centrolophus pompilus, Auct.) ought, on the other hand, as long ago byWilloughby, to be called Pompilus Rondeletii.

Brama Raii, Bl. "Freira."-Syn. Mad. Fish, p. 179.

The true affinities of this fish are most assuredly Scombridal, or to speak more strictly, Coryphænidal.

It was in reconsidering those of Brama, and in reaching this conclusion, that $I$ was first led to detect the true affinities and synonyms of Leirus. It was not till convinced of the necessity of placing Brama next to Pompilus (Centrolophus, Lac.), that I discovered Leirus Bennettii to be a genuine species of this last-named genus.

So valuable are these studies of affinities; and thus do even errors often lead to valuable truth. I was not wrong, however, in associating Leirus Bennettii with Brama; but in not referring sooner it, or rather both, to the neighbourhood of Pompilus.

\section{Fam. ZeNIDN.}

\section{Zeus Faber.}

\section{Fam. Mugilide.}

\section{Mugin maderensis. "Tainha de moda."}

This is the fish published, in the former part of this list, under the name and with the synonyms of $M$. Chelo, Cuv. Comparing it, however, more closely with the description of $M$. Chelo in the eleventh volume of MM. Cuvier and Valenciennes' Histoire, I find the follow. ing principal discrepancies in the Maderan fish : 
1. The produced scaly appendages at the base of the first dorsal fin extend considerably beyond the base of the fourth spine.

2. The maxillary is but very slightly S-like.

3. The upper lip is by no means peculiarly thick and fleshy, but rather the contrary.

4. It is a shallower, less deep fish in proportion to its length.

5. The tongue is altogether smooth, without any "asperités" whatever, at the edges or anterior end of the "arête," which cannot be called " très-aigue."

6. The palate also is entirely smooth, not papillose near the vomer.

7. A conspicuous bright metallic brassy spot on the opercula, as in $M$. auratus, Cuv, and Val.

It differs, however, essentially from this last-named species, and from $M$. breviceps, Cuv, and Val., in the exposure of the ends of the maxillary.

\section{Fam, Goridz.}

Having considerably extended my list of species, as well as rectified some errors in the nomenclature of others, I subjoin a complete enumeration of the Maderan species of this family hitherto discovered.

Blennius gattorugine, Will. Cuv. and Val. IX. 200. Will. Ichth. 132. t. H. 2. f. 2.-Yarr. 1, 226. Rariss.

A single individual only has occurred.

Blennius palmicornis, Cuv, and Val. XI. 214. t. 320. Syn. Mad. Fish 185. Vulgaris.

Blennius Artedii, Cuv, and Val. XI. 231. - incqualis nob. Synops. Mad. Fish 185. haud Cuv, et Val. Rarior.

This is the little fish which, being formerly known to me only by a sketch, I had erroneously supposed to be referrible to $B$. inaqualis, Cuv. and Val. On better acquaintance it however proves their $B$. Artedii ; and is indeed a most distinct and well-marked little species, scarcely exceeding two inches in length, and at once characterized by its active lively habits, its light tawny brown or yellowish olive colour, sprinkled all over with numerous minute white specks or dots, and the hollow, triangle-shaped, ciliate, occipital crest.

Blennius parvicornis, Cuv. and Val. XI. 257. Syn. Mad. Fish 185. Rariss.

Of this, as formerly of $B$. Artedii, I have no means of judging, except from some notes and a drawing taken by Miss Young, July 10th, 1835, during my absence from the island. My friend $\mathrm{Mr}$. Yarrell has, however, examined the individual from which these were taken; and on his accuracy I rely entirely for the correctness of the 
above name or reference. I had before supposed it to be undescribed, calling it $B$. strigatus.

Pholis levis, Flem. Cuv. and Val. XI. 269. Yarr. 1, 230. Syn. Mad. Fish 185. Rarior.

I cannot help suspecting that MM. Cuvier and Valenciennes' Maderan specimen at least, discovered by my friend Henry Richardson, Esq., of Aber Hirnant, North Wales, of Blennius trigloides, Cuv. and Val. XI. 228, is really nothing but this state or variety of Pholis lavis, which differs from the ordinary European fish only in having five or six distinct dark blotches or "demi-bands" along the back. I have hitherto met with no other fish beside the present answering at all to their description of $B$.trigloides; whilst this state of Pholis lavis, although somewhat rare, is by no means so uncommon as to have been likely to escape Mr. Richardson's unwearied assiduity.

Salarias atlanticus, Cuv. and Val. XI. 321. Syn. Mad. Fish 185. Vulgaris.

Tripterygion nasus, Riss. Cuv. and Val. XI. 409. Syn. Mad. Fish 185. Rariss.

Gobius Niger, $\beta$. nob.

$\longrightarrow$, L. Syn. Mad. Fish 185.

Gobius Maderensis, Cuv. and Val. XII. 55. Rarior.

I believe this to be a mere variety or state of the common European G. niger, Cuv. and Val., analogous to the above-mentioned Maderan state of Pholis lavis, Flem.

Gobius ephipriatus, $G$. fuscus, maculatus et punctatus: capite nuchaque nudis, hac sulcata : pinnarum pectoralium dorsaliumque radiis haud productis : squamis magnis.

D. $1^{\mathrm{ma}} .6 ;$ D. $2^{\text {da }} .12 ;$ A. $11 ;$ P. $19 ;$ V. $5 ;$ C. $\frac{5 \text { v. } 6}{5 \text { v. } 6}+\mathrm{XV}$; B. M. 5. Rariss.

Of a nearly uniform brown colour, a little paler on the belly, with a row of darker rich brown patches along the sides, and above these numerous scattered smaller spots. Head spotted. The spots on the head and fore part of the body are ocellate, or surrounded by a ferruginous or yellow ring. The eyes are scarcely a semidiameter apart. The ventral fins are united, but by a very low membrane in front. Length of the only individual which has hitherto occurred, five inches. It appears sufficiently distinct from all the described European species by its naked head and nape.

Fam. Lophide.

Cheironeotes bicornis. C. hispidus, setis furcatis, nudus sexappendiculatus, pallide ruber, punctutis fuscis conspurcatus: 
fronte super oculos bicorni; cornu anteriore distincto, recurvo; posteriore gibboso-cristiformi; filamento intermedio inconspicuo: brachiis pectoralibus ventralibusque exsertis.

D. 12 ; A. 7 ; P. $10 ;$ V. $5 ;$ C. $\frac{1+1}{1+1}+$ V.

A single individual only has occurred of this pretty little species, which in the foregoing characters appears distinct enough from all enumerated by MM. Cuv. and Val.; approaching, perhaps, nearest to Ch. furcipilis, pardalis, or coccineus. It was only one and threefourths of an inch long, and seven-eighths of an inch deep. The whole fish is strongly scabrous to the touch.

\section{Fam. Labrida.}

Crenilabrus caninus, nob. Synops. 186.

A most remarkable variety of this fish has the preopercle perfectly entire; invalidating thus completely the generic character. This state of the species appears permanent, and independent of age or size; whilst it is wholly unaccompanied by other marks of difference or indications of disease. It is rare comparatively with the normal form.

Crenilabrus luscus, nob. in Syn. Mad. Fish 187; nec Yarrellii nec Linnæi.

This also proves distinct from Mr. Couch's Scale-rayed Wrasse (Acantholabrus Couchii, Cuv. and Val. 13. 248), to which, as figured by Yarrell for the Labrus luscus, L. (a true Labrus, according to Valenciennes,) I had formerly referred it. A still nearer ally appears, however, to be Acantholabrus Palloni, Cuv, and Val. 13. 243 (Crenilabrus exoletus, Risso, haud Labrus exoletus, L.). From this it differs in the extension up between each of the spines of the dorsal and anal fins of generally four of the large scales into a curious distinct and moveable imbricated appendage ; in the large dark spot or patch on the hinder end of the spiny portion of the dorsal fin; in having two dark spots on each side at the base of the caudal fin, one on the dorsal, and another fainter on the ventral line; and lastly in the general colour. In the first and last of these four points, it agrees better with Acantholabrus Couchii, Val. (Crenilabrus luscus, Yarr., Brit. Fish. 1. 300); but it differs in the other two, is only half the size, and whilst the dorsal and the anal fins have severally one spine less, the dorsal has one soft ray more.

IAABRUS RETICULATUS.

'This fish cannot be at present safely referred to the Ballan Wrasse of British Authors (Labrus maculatus, Bl.), Yarr. 1. 275; although 
in size and form of body, no less than in the peculiar lowness of the spiny portion of the dorsal fin, and abrupt production of the soft part of the same, and of the anal fin, as well as in the number of the rays of all the fins, there is a strong agreement. It will, I think, howerer, ultimately prove merely a dark variety of that species. The colour is peculiarly sombre ; being a dark brown, approaching on the back almost to black; the whole beautifully reticulated with dark chesnut-brown lines, forming a border to each scale, and leaving the centre pale. The preoperculum was scaly. A single individual occurred in March 1838, and measured sixteen inches in length. Its fin-formula was,

D. $19+11 ; A .3+9 ;$ P. $14 ;$ V. $1+5 ;$ C. $\frac{4+\overline{1+V I}}{3+\overline{1+V .}} ;$ B. M. 5.

This individual has been deposited in the Society's collection.

JULIS MExanURA. J. oblongus, postice nigrescens : capite superne dorsoque olivaceo-fuscis: lateribus perpendiculate strigatis; strigis posterioribus nigricantibus : pinnce dorsalis antice altiores rudizs tribus primordialibus longioribus, operculique angulo lato truncato, basique primarum pectoralium ceruleo-nigrescente notatis : pinna dorsali analique fasciatis, basi nudis; caudali rotundato nigricante: squamis parvis: dente solitario majore ad canthum oris utrinque, antrorsum porrecto.

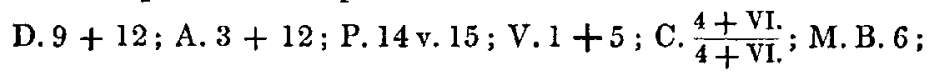
Verte. 25 .

Julis speciosa, nob. in Syn. Mad. Fish 186; haud Rissoi.

empla Canariensia, et forsan quidem Maderensia.

On re-examination and a close comparison of this fish with MM. Cuvier and Valenciennes' description of the true Mediterranean $J$. speciosa, of Risso, I find that it is properly distinct; although a Canarian individual at least of it has been referred by Valenciennes, as the Maderan fish was formerly by me, to Risso's species. It differs chiefly in the elevation of the three first rays of the dorsal fin, the spot on which is small, not large; in the deep blackness of the caudal fin and hinder part of the tail or body ; and, lastly, in being of considerably larger size (8-10 inches in length) than the true Mediterranean $J$. speciosa, Riss. Not having met at present with any other fishes in Madeira which agree so nearly as $J$. melanura with that species, I cannot help suspecting that in M. Valenciennes' Maderan specimens of his $J$. speciosa may exist the principal peculiarities which he has expressly noted in Mr. Webb's Canarian example, and which are precisely those of Julis melanura. 
Acantholabros imbricatus. A. pinna dorsali analique basi squamosis; squamis subquaternis, bractearum modo imbricatis, inter spinas assurgentibus : dorsalis parte spinosa postice unimaculato : cauda utrinque bimaculata: squamis magnis.
D. $20+9 ;$ A. $5+8 ;$ P. $15 ;$ V. $1+5$;
C. $\frac{3 v \cdot 4}{3 \text { v. } 4}+1 I I ;$ M.B. 5 .

Fam. Fistularida.

Centriscus gracilis. C. corpore gracili, angusto, elliptico-oblongo, supra fusco, lateribus argenteis: rostro producto, elongato: pinne prime dorsalis, inter oculos pinnamque caudalem media, spina secunda mediocri, breviore, pinnam caudalem nequaquam attingente.

$1^{\text {ma }}$ D. 4 v. $5 ; 2^{\text {da }}$ D. $11 ;$ A. $17 ;$ V. $1+4 ;$ P. $15 ;$ C. $\frac{7+\mathrm{IV}}{7+\mathrm{V}}$. Rarior.

In its shape and colour this is very obviously different from the common red Snipefish (C. Scolopax, L.). But I have not been able to assure myself that the above differences are not sexual. They are not certainly dependent upon size. The depth averages from onefifth to one-sixth and a half of the whole length, instead of onefourth of the same. In two individuals of the same length within one quarter of an inch, the depth of the larger (C. Scolopax, L.) was very nearly double that of the smaller (C. gracilis, nob.) and the 2 nd spine of the lst dorsal fin was respectively in each one-fourth and one-seventh of the whole length of the fish.

\section{Fam. Esocidx.}

\section{Belone gracilis, nob.- "Catuta."}

Early in March last year (1838) a fisherman brought alive in seawater two fishes, which, in their slenderness, and the upper jaw being only half the length of the lower, differed obviously from the common B. vulgaris. Measuring, however, seven or eight inches only in length, it seemed questionable, in the absence of equal-sized individuals of $B$. vulgaris for comparison, whether they might not be the young of that species. My friends, however, the Rev. L. Jenyns and Mr. Yarrell, have examined these two individuals, and the latter warrants me in stating, on their joint authority, that these two fishes are " not, in their opinion, B. vulgaris," being " much more slender for the same or equal length."

Scomberesox Saurus, Cuv.

The Portuguese name "Delphine" (rectius "Delfim",) is erroneously appended to this fish. Another individual has been lately brought to me with the name of "Almeirão," but the species is far 
too rare to have obtained any permanent and genuine appellation in Madeira.

\section{Fam. Salmonida.}

\section{Scopelus manerensis.}

A small dark mulberry-coloured fish, which might easily be taken for the fry or young of Pomatomus telescopus, Risso. The dark vinous-coloured ground is concealed by very large deciduous platinalike scales. The only individual which has yet occurred was three inches long. It approaches very near to Sc. Humboldti, Risso, Hist. iii. 467. (supposed to be identical with Pennant's Argentine, Yar. 11. 94.), and has the row of longer silver dots, or pits, extending forwards from the root of the caudal fin along the ventral line : but it disagrees remarkably with the generic characters assigned to Scopelus by $\mathrm{Cu}$ vier, R. An. 2nd Ed. ii. 314, in having both the palatines and tongue aculeate with teeth.

The fin-formula in the Madeiran fish was

Ist, D. $3+10$; 2nd, D. 1 club- or feather-shaped ;

$$
\text { A. } 2+12 ; \text { P. } 13 ; \text { V. } 1+7 ; \text { C. } \frac{7+\overline{\mathrm{I}+\mathrm{IX}}}{6+\overline{\mathrm{I}+\mathrm{VIII}}} \text {. }
$$

Gen. Axysia.

Corpus subelongatum, compressum; dorso postice ventreque spinososerratis. Rostrum brevissimum, ore rictuque magnis, hoc pone oculos diducto. Dentes minuti, tenues; in maxilla inferiore, Vomere, et Palatinis scobinati. Lingua postice lateribus subaculeolata.

Squama magnæ, haud deciduæ, scabræ; squamis lineæ lateralis latissimis, maximis, scutellatis, s. per totam longitudinem loricatoimbricatis.

Pinne ventrales sub apice pinnarum pectoralium sitæ. Dorsales duæ; prima inter Ventrales et Analem posita; $2^{\text {da }}$ ad finem analis, rudimentali. Pinna caudalis minima, furcata.

\section{Arysia ronicata.}

The spinoso-serrate ventral and hinder part of the dorsal lines, together with the peculiar scales of the lateral line, appear to forbid the blending of this interesting little fish with the Cuvierian genus Aulopus, as defined in the R. Anim., Ed. 2. ii. 315, though they have many characters in common. The Maderan fish is no less rare than elegant. It scarcely exceeds two inches in length. The back is a deep blue; the sides bright silvery or platina; and a row of deadsilver dots or pits extends along the ventral line, as in the Scopelus above described. The fin-formula is 
1st, D. $2+10$; 2 nd, D. rudimentary; A. $2+21$ (+8 detached depressed points or spines); P. 15 or $16 ; \mathrm{V} .1+5$; C. $\frac{4+\overline{\mathrm{I}+\mathrm{IX}}}{3+\widetilde{\mathrm{I}+\mathrm{VIII}}}$.

Fam. Gadida.

Macrourus atlanticus.—"Praga" or "Lagartixa do mar."M. fusco-cinereus, dorso vinoso, gutturis umbilico pinnisque ventralibus atris : squamis areolato-scaberrimis, echinalatis, ecarinatis, inermibus: oculis maximis.

M. rupestris, nob. in Synops. Mad. Fish, p. 190, nec Bl. nec Cuv. et omiss. syn. Lepidoleprus colorhynchus, Risso.

On further examination, this most singular fish appears to be quite distinct from $M$. rupestris, Bl. t. 177; and therefore, according to Cuvier (R. Anim. 2nd Ed. ii. 337, note,) from Lepidoleprus ccelorhynchus, Risso, through which indeed alone I had referred it to the northern fish described by Bloch. But besides the points included in the specific character, the first ray of the first dorsal fin is neither serrate nor stronger than the rest. The diameter of the eye is one twelfth or one thirteenth part of the whole length, which scarcely exceeds one foot.

\section{Fam. Peeuronectida.}

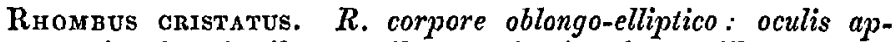
proximatis: dentibus tenuibus pectinatis; in maxilla superiore uniseriatis; in inferiore anguste scobinatis : pinnce dorsalis dimidii anterioris radiis apice liberis; primordialibus $\left(2^{\mathrm{do}} 6^{\mathrm{m}}\right.$.) productis, elongatis : latere (sinistro) fusco, immaculato: squamis (haud deciduis) magnis, margine scabris.

D. 92 ; A. $75 ;$ V. 6 ; P. $1+9 ;$ C. $\frac{3+\mathrm{VI}}{3+\mathrm{V}}$. Rariss.

The Whiff of British authors (R.megastoma, Yarr. 2. 251) appears the nearest ally of this apparently new species. Indeed, except for Mr. Yarrell's more detailed account, I should have scarcely perhaps scrupled referring it to "La Cardine ou Calimande" of Cuvier's R. Anim. 2. 341, of which he says, "ses premiers rayons sont libres"; of course meaning of the dorsal fin. Nothing is, however, discernible of this in either Mr. Yarrell's figure or description of "The Whiff"'; nor even, if correct, does it express sufficiently the peculiarity of this part in the Maderan fish. The only individual which has yet occurred was five and a quarter inches long.

Fam. Cyclopterine.

43. Lepadogaster zebrinus.- " Chupa sangue." L. fusco-nigrescens, lateribus postice strigis obliquis, nuchaque fasciis diver- 
gentibus saturatioribus maculisque binis caruleis pyriformibus pictis: naribus biciliatis : pinnis dorsalibus unalibusque caudali adnatis.

D. 17 v. 16 ; A. 10 v. 9 ; P. 15 v. $16 ;$ Vs. 4 ; C z + X. Haud rara.

In the double nasal cilia, and connexion of the caudal with the dorsal and anal fins, this little fish agrees with $L$. cornubicus (Flem.), Yarr. 2. 264. The structure of the sucking disk is also similar to the representation of the same part in that species, and not to that of the "bimaculated Sucker," at p. 268. In this particular it perfectly agrees also with the former species indicated in my Synopsis, p. 190; which is, however, perfectly distinct specifically, having neither a nasal cilium nor the caudal fin united with the dorsal and anal fins. Of this last-mentioned species no second example has yet occurred. The present (L. zebrinus) is not by any means uncommon. It varies considerably in intensity of colour, and in the distinctness of the darker stripes upon the nape and flanks. The nasal cilia are of the general dark brown or blackish tint.

Fam. Echeneide.

SS. Cauda lunata.

Echeneis Remora, L. Syst. Ed. 12.-“Pegador." E. tota cinereofuliginosa, nigrescens: laminis disci xvii. v. xviii.; pinnis pectoralibus brevibus, ovatis, integris, apice rotundatis: lingua lavi.



Echeneis pallida. E. tota pallide cinerea, fuligineo hinc et hinc subnebulata: laminis xix.; pinnis pectoralibus brevibus, latis, apice rotundatis, subtruncatis, tenuiter crenulatis : lingua medio scobinata.

D. 24 ; A. 22 ; P. 27 ; V. $1+5$; C. $\frac{3 \text { v. } 4+\text { VIII }}{3 \text { v. } 4+\text { VII }}$ M. B. 9. Rariss.

SS. Cauda integra, S. truncata.

ECheneis JасоваA.-E. tota cinereo-fuliginosa, nigrescens: laminis xix.: pinnis pectoralibus brevibus, latis, pectinato-rotundat is crenatis: ventre sulcato : lingua scabra.

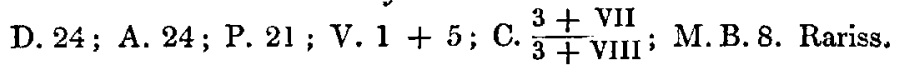

EcheNEIS viTTATA.-E. purpureo-nigrescens, pallido variegata, fasciaque nigra longitudinali laterali, antice utrinque albo marginata: pinnis pectoralibus ovatis, acutiusculis, integris; pinna dorsalis analisque antice caudalisque marginibus albis: laminis xxiv.: lingua scabra: oculis magnis: corpore elongato, postice valde attenuato, gracili. 


\section{39 ; A. $39 ;$ P. $22 ;$ V. $1+5$; C. $\frac{1+\text { VIII }}{1+\text { VII }}$. Kariss.}

The nearest ally of this very distinct species appears to be $E$. $l u$ nata. Bancr. in Zool. Journ. V. 413. t. 18. But this, besides other differences, has a lunate tail.

Echentis brachyptera. (Echeneis ? ? Syn. p. 191.) E. cinereo-fuliginosa, nigrescens; pinnis dorsalibus analibusque antice albo submarginatis : laminis xvi.: pinnis pectoralibus brevibus, latis, truncatis, integris : lingua medio scobinatu.

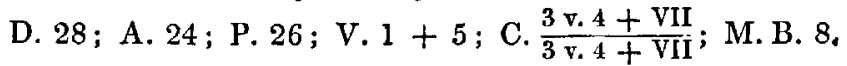

This is the first of the two species indicated by me in the former part of this List or Synopsis. Of the second sort, there mentioned as having been seen by Miss Young, and which I have there doubtfully referred to $E$. naucrates, L., no fresh example has occurred. I should now be much inclined to consider it identical with $E$. vittata ; but Miss Young affirms that it was " certainly plain-coloured."

\section{Fam. Murenida.}

Sphagebranchus serpens.

S. serpa, Risso, Hist. Nat. iii. 195. No. 81.

A single individual only has occurred, precisely answering to the description above referred to. It measured eleven inches in length. I could not detect the slightest rudiment of pectoral fins.

Fam. Gymnodontide.

Tetrodon capistratus. T. pusillus, oblongiusculus levissimus; dorso iliisque inermibus, nudis ; ventre adpresso-spinelloso : dorso fusco; lateribus ochraceo-fulvis, fusco longitudinaliter bifasciatis, capiteque utrinque caruleo punctatis, iliis oblique lituratis, rostroque subproducto gulave semi-capistrato : pinna caudali utrinque nigro-limbata.

D. 9 ; A. 8 ; P. 16 ; C. $\frac{2}{2 \text { v. } 3}$ + VIII. Rariss.

A most elegantly-coloured little species, which I cannot refer with certainty to any already described. Only two individuals have hitherto occurred. The first was little more than two inches long; the second nearly twice as large.

The Orthagoriscus of Madeira, called by the fishermen, "Peixe Porco," or "Bouto," I forbear at present to designate further, not having seen a sufficient number of individuals to determine its characters. The caudal fin is produced into a short point in the middle, not truncate, as in all the figures to which I have access of the European Sun-fishes. 


\section{Fam. Squalida.}

Carcharrus halcipinnis. "Faqueita." C. corpore supra griseocinereo, subabbreviato, medio crassiore s. altiore, utrinque altenuato: rostro brevi, lato, depresso, apice obtuso: oculis rotundatis : pinna dorsali prima alta, triangulari, subantica s. supra medium pinnarum pectoralium posita: pinnis pectoralibus falcatis, angustis, elongatis, apice obtusis : pinna dorsali secunda analique oppositis : ventralibusque parvis. Rariss.

An Squalus ustus, Dum.?

It is perhaps only for want of better materials for comparison that I have been unable to refer this Shark precisely to the above-indi. cated or to some other described species. It is about three feet long. and the female differs in nothing from the male. The teeth are precisely similar to those of the "Tintureira" (C. glaucus, Cuv.).

The "Marraxo" proves to be, as I suspected, Lamna cornubica, Cuv., adult, or of large size.

\section{Gen. Acanthimium.}

Corpus gracile, elongatum. Spiracula magna. Pinne dorsales duæ, antice spiniferæ; secunda majore postica, caudæ approximata. Pinna analis nulla. Pinna ventrales, subposticæ s. secunda dorsalis subanteriores.

Dentes utriusque maxillæ dispares, parvi : superioris laniarii, planotriangulares, tenues, acuminati; acumine recto; basi utrinque denticulo aucto; antice triseriati, lateribus biseriati : inferioris incisorii, acumine utrinque a medio oblique deflexo, uni- vel bi-seriati. Cauda oblique oblonga, apice truncata.

This new genus appears exactly intermediate between the established genera of Cuvier, Spinax and Centrina: agreeing with the former in its elongated form, and with the latter in the teeth.

The ventral fins are placed more backward than in Spinax, but rather forwarder than in Centrina, i. e. neither halfway between the two dorsal fins, nor opposite the second dorsal fin, but just before the second dorsal fin, which begins exactly opposite the termination of their base. The tail or caudal fin resembles that of Spinax, rather than of Centrina, and the spines of both the dorsal fins are reflexed as in Spinax, forming the fore-edge of each fin. The pectoral fins are abruptly truncate. The second dorsal fin is greatly larger than the first; in which it differs equally from Spinax and Centrina. The teeth are not arranged quincuncially, but behind each other in rows.

Two species have occurred, both of which have hitherto been confounded with Centrina. 
Acanthidium pusillum. "Gata negra." $A$. totum atrum, pusillum: rostro crassiusculo: dentibus inferioribus uniseriatis : spiraculis oculo remotiusculis.

Centrina? nigra, nob. olim in Proceed. Zool. Soc. 1833, p. 144*. Syn. Mad. Fish in Trans. Zool. Soc. p. 194. Rariss.

Four individuals of this curious little shark have now occurred, agreeing equally in the foregoing characters and in their dimensions, varying in length only from eleven to twelve inches. The second dorsal fin is somewhat forwarder or more distant from the origin of the tail than in the next species.

The condition of the teeth, and constancy of size, both indicate an adult fish; and a comparison of the present species with the foetal and adult state of the following, in these two points alone demonstrates Acanthidium pusillum to be no stage of $A$. calceus.

Acanthintom calceus. "Sapata." A. purpureo-fuscum, subtus pallidius: rostro plano-depresso: dentibus inferioribus biseriatis: spiraculis oculo, pinnaque dorsali secunda caude approximatis.

Centrina Salviani, Syn. Mad. Fish in Trans. Zool. Soc. p. 194 : nec aliorum. Rarior.

This shark very much resembles in its general aspect Scymnus niccensis, Risso, the " Gata" of Madeira : but is at once distinguished by the spines in front of the two dorsal fins, which, as in A.pusillum, are both recurved, and ought, had I attended to the excellent figures copied by Willoughby from Salviana of Centrina nigra, Cuv., instead of allowing myself to be deceived by a miserable figure of Lacepède's, alone to have preserved me from the blunder of referring to that species for the present shark, the usual size of which exceeds by a few inches only three feet.

Fam. Rainda.

Raia oxyrhynchus, Will., Ichth. p. 71.-“Raia."

Sharp-nosed Ray, Penn., Ed. 1. iii. 83. No. 31. Yarr., Brit. Fish. ii. 424 .

Two male individuals only have occurred: the largest, measuring three feet in width from wing to wing, was furnished on the back with patches of strong hooked spines or prickles, much is in the figure in the British Fishes; but the second example, scarcely two

* A serious erratum has been caused here by the transposition of a sentence. The paragraph referred to should stand thus: "It (Centrina? nigra) is intermediate in characters between Centrina, Cuv., and Acanthias, Risso, having the teeth of the former genus as well as the backward position of the second dorsal (rectius ventral) fin, and the form of body of the latter." 
feet wide, although decidedly a male, was devoid of these appendages. The colour of the upper surface was a pale, dull, yellowish, or ashy-grey, obscurely mottled or dappled with a few scattered distant paler whitish spots.

Trygon altavela.- "Andorinha do mar." T. corpore rhomboideo, duplo latiore quam longo, alis expansis, cauda perbrevi.

Pastinaca marina altera $\pi \tau \epsilon \rho v \pi \lambda \tau \tau \epsilon i \bar{a}$, Altavela Neapoli dicta Colum ne. Will., Hist. 65. Tab. C. 1. f. 3. (Copied from F. Columna.)Rariss.

A single female individual only has occurred, measuring five feet and a half from tip to tip of wings.

\section{LII.-Information respecting Botanical Travellers.}

Extracts from a Journal of the Mission which visited Bootan, in 1837-38, under Captain R. Borleav Pemnerton. By W. Grifрттн, EsQ. Madras Medical Establishment*.

The Mission left Gowahatti on the 21st December, and proceeded a few miles down the Burrumpootur to Ameengoung, where it halted.

On the following day it proceeded to Hayoo, a distance of thirteen miles. The road, for the most part, passed through extensive grassy plains, diversified here and there with low rather barren hills, and varied in many places by cultivation, especially of sursoo. One river was forded, and several villages passed.

Hayoo is a picturesque place, and one of considerable local note; it boasts of a large establishment of priests, with their usual companions, dancing girls, whose qualifications are celebrated throughout all Lower Assam. The village is a large one, and situated close to some low hills; it has the usual Bengal appearance, the houses being surrounded by trees, such as betel palms, peepul, banyan, and caoutchouc. To Nolbharee we found the distance to be nearly seventeen miles. The country throughout the first part of the march was uncultivated, and entirely occupied by the usual coarse grasses; the remainder was one sheet of paddy cultivation, interrupted only by topes of bamboos, in which the villagers are entirely concealed; we found these very abundant, but small : betel palms continued very frequent, and each garden or enclosure was surrounded by a small species of screw pine, well adapted for making fences.

Four or five streams were crossed, of which two were not fordable : jheels were very abundant, and well stocked with water fowl

- From the Journal of the Asiatic Society of Bengal, No. 87, p. 208. 